\title{
Holocene climate variability in southern Greenland: results from the Galathea 3 expedition
}

\author{
Niels Nørgaard-Pedersen, Naja Mikkelsen, Majken Djurhuus Poulsen and Aaju S. Simonsen
}

The third Galathea expedition (Galathea 3) left Copenhagen in August 2006 for a circumnavigation of the globe with the aim of conducting more than 70 scientific programmes en route. The first geological programme took place in South Greenland and included sampling of sediment cores and seismic profiling. The aim of the study is to obtain detailed knowledge about Holocene climate changes and the glaciomarine history.

A number of cores with high sedimentation rates were collected near Narsaq in South Greenland (Fig. 1). Analyses of the cores elucidate the mid- to late Holocene climatic and environmental evolution of the area, which is highly influenced by the dynamic nature of the Greenland ice sheet and changes of the North Atlantic climate. Two major ocean currents, the cold East Greenland Current and the warmer (Atlantic Water) Irminger Current influence the deep fjords of the region, and the two currents are in turn influenced by both polar and lower latitude climate changes.

Evidence from ice cores and marine and lacustrine records in the North Atlantic region show a general climatic cooling from the mid- to late Holocene as a response to decreasing summer insolation. About 5000 years ago, a transition occurred from the Holocene thermal maximum to the Neoglacial (Dahl-Jensen et al. 1998). The cooling trend shows different timing and amplitudes in different parts of the North Atlantic region (Kaufman et al. 2004), and an apparent counterphase between the climatic conditions of western Greenland and north-western Europe during certain time periods has recently been suggested (Seidenkrantz et al. 2008).

Fig. 1. Map of South Greenland showing the main current systems and locations of investigated cores. The waters of the East Greenland Current and the warmer and more saline Irminger Current (deeper than $200 \mathrm{~m}$ ) form a stratified water column along the coast of southern Greenland.
The present study investigates climate changes in South Greenland in relation to the previously established pattern of Holocene palaeoceanographic and atmospheric changes as known from other North Atlantic palaeoclimatic studies.

\section{Study area and methods}

Glacially eroded and over-deepened fjords reaching depths of 600-700 m dissect South Greenland around Qaqortoq and Narsaq (Fig. 1). Sediment cores were collected in Bredefjord and Narsaq Sund (Fig. 1) using a gravity corer and a box corer at water depths of $270-670 \mathrm{~m}$. A gravity corer with a $750 \mathrm{~kg}$ lead weight was used to collect sediment cores up to $6 \mathrm{~m}$ long with a diameter of $12 \mathrm{~cm}$. Surface sediments were sampled with a cylindrical $30 \mathrm{~cm}$ diameter box corer. All cores were subsampled for analyses of microfossils and age determination using accelerator mass spectrometry ${ }^{14} \mathrm{C}$ dating. The cores were split lengthwise, and magnetic susceptibility was

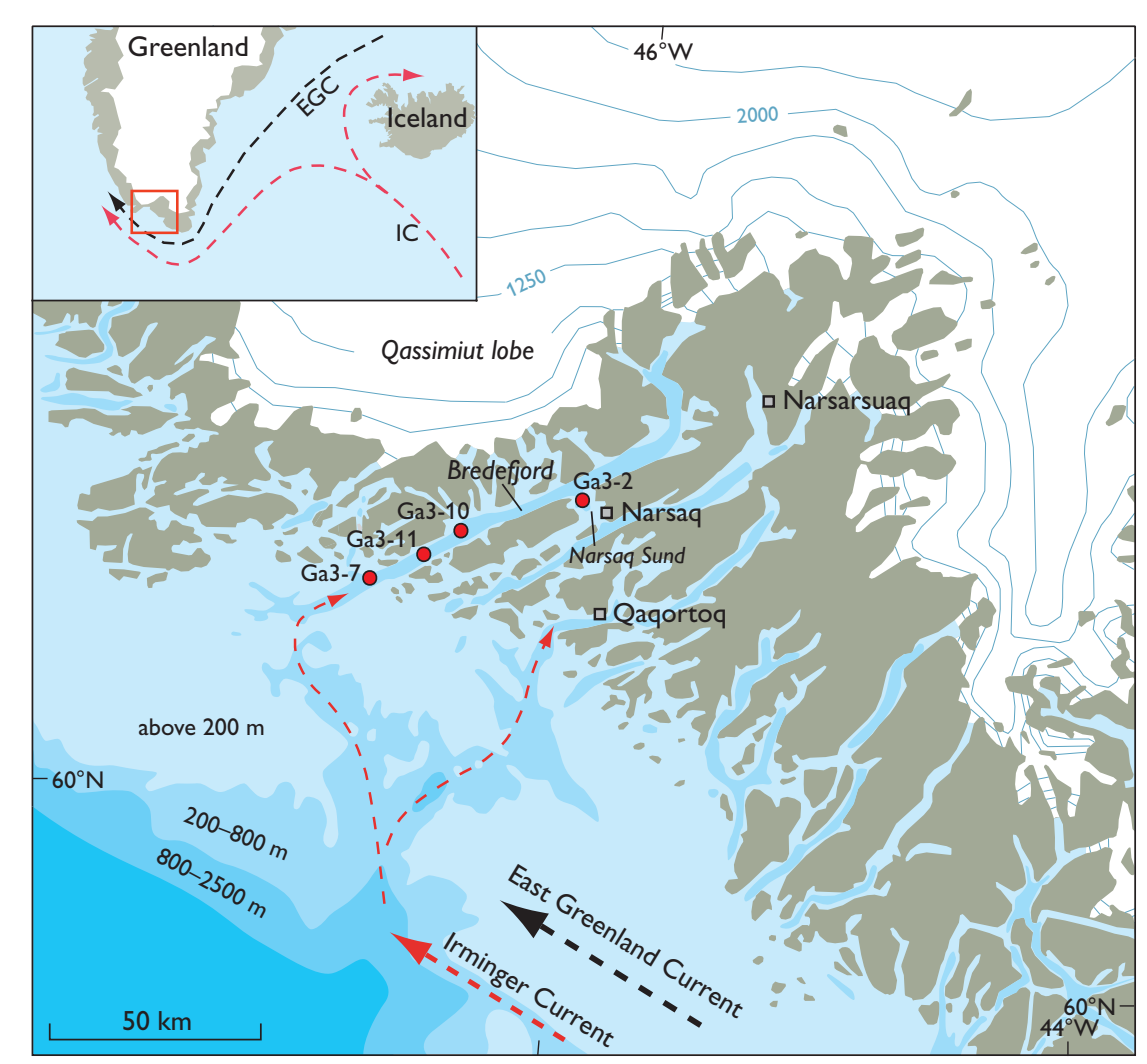


measured in high resolution using a Bartington MS2E1 probe. Nine samples of benthic foraminifera were used for ${ }^{14} \mathrm{C}$ dating at the Leibniz Laboratory for Radiometric Dating and Isotope Research in Kiel, Germany, and the box cores were analysed for ${ }^{210} \mathrm{~Pb}$ and ${ }^{137} \mathrm{Cs}$ content at the Gamma Dating Center, Department of Geography and Geology, University of Copenhagen. A number of basic sediment parameters were determined including sediment wet-bulk density, water content, dry-bulk density and grain-size distribution. Magnetic susceptibility measured at high resolution in general parallels the records of coarse-fraction content, and can therefore be used for correlation and as a high-resolution measure of coarse-fraction influx. In order to estimate the variation in bottom-current velocity, detailed grain-size measurements (range 0.01-1000 $\mu \mathrm{m}$ ) were carried out on bulk-sediment samples using a Malvern Mastersizer 2000 laser particle-size analyser at the Department of Geography and Geology, University of Copenhagen. The weighted grain-size means of the sortable silt fraction $(10-63 \mu \mathrm{m})$ were calculated and used as a proxy for bottom current. The number of lithogenic grains $>1 \mathrm{~mm}$ (coarse ice-rafted debris, IRD) was counted using a dissecting microscope. The rationale for using grains $>1 \mathrm{~mm}$ is a compromise between having an adequate number of grains and using grains so large that aeolian transport can be considered negligible. The IRD content is thus used as a proxy for rock fragments from melting of icebergs or sea ice deposited at the site.

The sediment-size fraction $125-1000 \mu \mathrm{m}$ was separated by dry sieving, and from this fraction 300-400 calcareous benthic foraminifera were picked for analyses. In sediment cores with a fairly uniform sedimentation rate and limited calciumcarbonate dissolution, the abundance of calcareous benthic foraminifera mainly reflects productivity related to food supply.

\section{Fjord environment and sedimentation records}

The records from the three gravity cores from Bredefjord are dominated by episodic turbidite sedimentation with very high sedimentation rates of up to $1 \mathrm{~cm} /$ year (based on a calibrated ${ }^{14} \mathrm{C}$ age from Ga3-7 (435 cm depth) of $c .465$ years $\mathrm{BP})$ and is under influence from meltwater supply and glacier calving from the adjacent margin of the Greenland ice sheet (Fig. 1). For this study, we selected core Ga3-2 from the adjacent Narsaq Sund (Fig. 1), which represents a continuous and more slowly accumulating $(c .70 \mathrm{~cm} / 1000$ years $)$ sedimentation record covering the last $c .8000$ years. The chronology is based on eight ${ }^{14} \mathrm{C}$ ages (Fig. 2). The record is characterised by a grain-size spectrum of dominantly suspension-settled mud modulated by variable bottom-current influence and IRD rain (Fig. 3). The sedimentation in this turbidite-sheltered part of the fjord system has been controlled by a number of related processes including influx of sediment-laden meltwater plumes with fine-grained sediment, iceberg calving and coarse-sediment IRD transport and strength and changes of fjord circulation/water-mass stratification by Irminger Current and East Greenland Current water masses

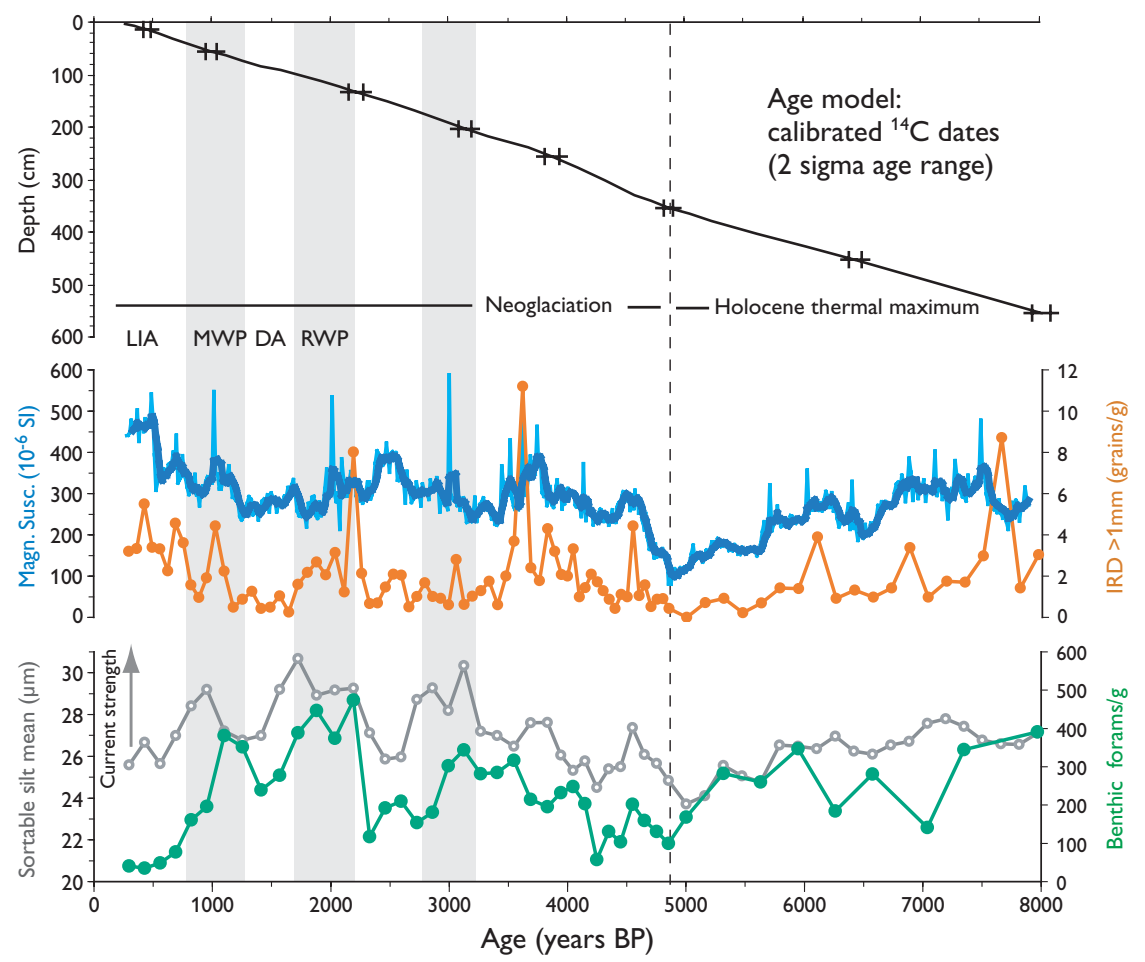

Fig. 2. The Narsaq Sund record (core Ga3-2). The chronology is based on ${ }^{14} \mathrm{C}$ age determinations of eight benthic foraminifera samples. Sediment parameters shown: magnetic susceptibility with five-point running mean, icerafted debris content (IRD $>1 \mathrm{~mm}$ ), weighted mean grain size of sortable silt (bottom current proxy), and abundance of calcareous benthic foraminifera/g dry sediment. The grey columns indicate periods of increased bottom currents during the Neoglaciation. European historical climate periods (cf. Lamb 1995) are indicated: LIA, Little Ice Age; MWP, Medieval Warm Period; DA, 'Dark Ages'; RWP, Roman Warm Period. 
penetrating into the fjord system (Ribergaard 2007). Modified Irminger water is found below c. $200 \mathrm{~m}$ water depths and East Greenland waters above. During the summer a local brackish meltwater-rich layer characterises the uppermost $10-15 \mathrm{~m}$ of the water column.

\section{The Narsaq Sund record}

The lower part of the Narsaq Sund record, deposited from about 8.0 to $4.8 \mathrm{ka}$ ( $\mathrm{ka}=$ thousand years before present), represents the Holocene thermal maximum and shows a progressive reduction in the supply of coarse-grained material, punctuated by increased influx of IRD at about 7.5-6.8 and 6.5-5.7 ka (Fig. 2). The interval 5.7-4.8 ka appears to have been characterised by markedly lower amounts of IRD, and it is suggested that this could reflect a situation in which several of the present tidewater glaciers terminated on land. The Neoglaciation appears to have started at about $4.8 \mathrm{ka}$, with peak values of IRD at about 4.6, 3.6, 2.2, 1.0, 0.7, and $0.5 \mathrm{ka}$ and onward (Fig. 2). Several of these IRD events appear to be associated with enhanced melting and glacier instability during warming episodes. On the other hand, a marked increase in IRD is noted at the transition to the Little Ice Age at about $0.55 \mathrm{ka}$. This appears to correlate with the maximum ice advance of the Qassimiut lobe (Weidick et al. 2004). A threshold may have been reached during this period, with a marked advance of tidewater glaciers to a new equilibrium state leading to increased IRD deposition in the fjords.

Assemblages of calcareous benthic foraminifera show that the bottom of Narsaq Sund has been dominated by modified Irminger water during most of the Holocene. Bottom-current flow seems to have been quite sluggish before $3.2 \mathrm{ka}$, whereas the late Holocene was characterised by pronounced episodes of increased bottom-current velocity and increased productivity of calcareous benthic foraminifera (Figs 2, 3). The first episode at 3.2-2.8 ka shows no relation to IRD/meltwater proxies and the timing at $3.2 \mathrm{ka}$ indicates that the episode may be related to a concurrent major reorganisation of the North Atlantic current systems (cf. Koç et al. 1993).
During two following periods, at c. 2.3-1.7 ka and $c .1 .3-0.8 \mathrm{ka}$, marked increases in bottom-water flow also occurred, and it is suggested that the fjord circulation during these time intervals was enhanced by an increased outflow of meltwater. The timing of the latter two events may imply a link to climate changes during the European Roman Warm Period and the Medieval Warm Period (cf. Lamb 1995).

Radiocarbon dating and palaeoecological studies show that the fjord system became ice-free at 13 to $9 \mathrm{ka}$ and the East Greenland Current and the Irminger Current entered the deep and glacially eroded fjords (Weidick et al. 2004). During the recession of the Greenland ice-sheet margin from the region, large amounts of icebergs characterised the fjords, but with the onset of the Holocene thermal maximum at $8-5 \mathrm{ka}$, the temperature increased and became a few degrees higher than today. During the Holocene thermal maximum the Greenland ice sheet reached a minimum size. It became increasingly colder in southern Greenland after the thermal maximum, and with the onset of colder conditions during the Neoglacial period at 4-3 ka the glaciers readvanced. During the Little Ice Age that culminated around AD 1600-1850, the ice margin expanded several kilometres and the Greenland ice sheet reached its maximum size after the Holocene thermal maximum (Weidick et al. 2004). During the late Holocene southern Greenland subsided 6-8 $\mathrm{m}$, probably partly due to the re-advance of the Greenland ice sheet (Sparrenbom et al. 2006). At the present time most glaciers in Greenland display marked recession.

\section{The see-saw puzzle of Holocene North Atlantic climate}

Recently, Seidenkrantz et al. (2008) studied late Holocene marine records from West Greenland and found a complex relationship between the palaeoclimate of West Greenland and that of other parts of the North Atlantic region. Their study indicated that in West Greenland, the European Medieval Warm Period (c. 1.3-0.8 ka in the Greenland record) was characterised by a decreased influence of the warm
Fig. 3. Particle-size variation plotted against age for the Narsaq Sund Ga3-2 core. A distinct increase in the modal peak of the grain-size distribution occurred at about $3.2 \mathrm{ka}$. This suggests an increased bottom-water circulation in Narsaq Sund, which may be related to changes of the North Atlantic current systems or increased meltwater discharge.

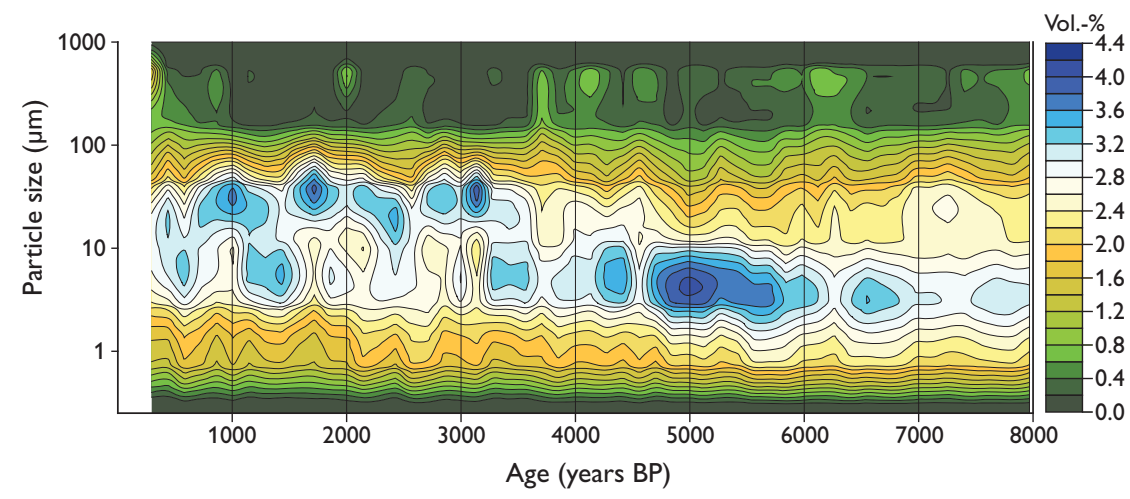


Irminger Current and thus a relatively cool climate, whereas the colder European 'Dark Ages' (c. 1.5-1.3 ka in the Greenland record) appear to have been characterised by a higher meltwater runoff and consequently a warmer climate (Seidenkrantz et al. 2008). In contrast, marine, lacustrine and ice-core studies from southern Greenland (e.g. Dahl-Jensen et al. 1998; Andresen et al. 2004) do not reveal a convincing climate see-saw trend between southern Greenland and northern Europe.

Southern Greenland is located on the main track of cyclones crossing the North Atlantic region on their way towards Iceland. Therefore the area has potential to provide crucial information on major shifts in the North Atlantic atmospheric circulation and general climate regime. The long-term pattern appears to follow climate changes consistent with patterns of East Greenland Current variability (Bond et al. 2001), which are partly related to the dominant North Atlantic oscillation (Buch 2002). This long-term seesaw pattern of the influence of the Irminger Current reported by Seidenkrantz et al. (2008) is evident in the recent North Atlantic record. Related changes in air temperature, sea-surface temperature, storm patterns, and sea-ice distribution offer a likely explanation for long-term changes and different regional climate trends in the North Atlantic region. There are, however, many unsolved questions in this puzzle, and more high-resolution records are needed from selected sites in order to investigate causes and links between regional climate variations in the North Atlantic region.

\section{Climate change and the demise of the Norse}

Norse immigrants settled around AD 985 in South Greenland where farming communities were established in the Eastern Settlement during the Medieval Warm Period. The Norse society no doubt had to cope with a number of socioeconomic and environmental problems that eventually caused their disappearance after almost 500 years of existence in Greenland. One of their problems was the general temperature decrease at the transition from the Medieval Warm Period to the Little Ice Age, discussed by Mikkelsen et al. (2008). This transition may have brought their living conditions to a critical point although the manner of the demise of the Norse people is still an unsolved question. Temperature decrease, increasing storminess and sea-ice increase threatened the existence of the Norse people and presumably led them to gradually leave Greenland - perhaps for Iceland from where their pioneer ancestors originally set out.

\section{Acknowledgements}

We thank captain and crew of the Danish naval ship Voedderen for their help and support during the cruise. We gratefully acknowledge financial support from the BG Fund, Det Kongelige Grønlandsfond and the Commission for Scientific Research in Greenland. This is publication no. P29 on the scientific outcome of the Galathea 3 expedition in 2006-2007.

\section{References}

Andresen, C.S., Björck, S., Bennike, O. \& Bond, G. 2004: Holocene climate changes in southern Greenland: evidence from lake sediments. Journal of Quaternary Science 19, 783-795.

Bond, G., Kromer, B., Beer, J., Muscheler, R., Evans, M.N., Showers, W., Hoffmann, S., Lottibond, R., Hajdas, I. \& Bonani, G. 2001: Persistent solar influence on North Atlantic climate during the Holocene. Science 294, 2130-2136.

Buch, E. 2002: Present oceanographic conditions in Greenland waters. Danish Meteorological Institute, Scientific Report 02-02, 39 pp.

Dahl-Jensen, D., Mosegaard, K., Gundestrup, N., Clow, G.D., Johnsen, S.J., Hansen, A.W. \& Balling, N. 1998: Past temperatures directly from the Greenland ice sheet. Science 282, 268-271.

Kaufman, D.S. et al. 2004: Holocene thermal maximum in the western Arctic $\left(0-180^{\circ} \mathrm{W}\right)$. Quaternary Science Reviews 23, 529-560.

Koç, N., Jansen, E. \& Haflidason, H. 1993: Palaeoceanographic reconstructions of surface ocean conditions in the Greenland, Iceland and Norwegian Seas through the last 14 ka based on diatoms. Quaternary Science Reviews 12, 115-140.

Lamb, H.H. 1995: Climate history and the modern world, 433 pp. London: Routledge.

Mikkelsen, N., Kuijpers, A. \& Arneborg, J. 2008: The Norse in Greenland and late Holocene sea-level change. Polar Record 44, 45-50.

Ribergaard, M.H. 2007: Oceanographic investigations off West Greenland 2006. Northwest Atlantic Fisheries Organization, Scientific Council Documents 07/1(N5339), 48 pp.

Seidenkrantz, M.-S., Roncaglia, L., Fischel, A., Heilmann-Clausen, C., Kuijpers, A. \& Moros, M. 2008: Variable North Atlantic climate seesaw patterns documented by a late Holocene marine record from Disko Bugt, West Greenland. Marine Micropaleontology 68, 66-83.

Sparrenbom, C.J., Bennike, O., Björck, S. \& Lambeck, K. 2006: Holocene relative sea-level changes in the Qaqortoq area, southern Greenland. Boreas 35, 171-187.

Weidick, A., Kelly, M. \& Bennike, O. 2004: Late Quaternary development of the southern sector of the Greenland Ice Sheet, with particular reference to the Qassimiut lobe. Boreas 33, 284-299.

\section{Authors' addresses}

N.N.P. \& N.M., Geological Survey of Denmark and Greenland, Øster Voldgade 10, DK-1350 Copenhagen, Denmark. Email: nnp@geus.dk

M.D.P., Department of Geography and Geology, University of Copenhagen, Øster Voldgade 10, DK-1350 Copenhagen K, Denmark.

A.S.S., Department of Geology, University of Tromsø, N-9037 Tromsø, Norway. 